\title{
Cardiometabolic risk among schoolchildren born at term and premature
}

\author{
Risco cardiometabólico entre escolares nascidos a termo e prematuros \\ Riesgo cardiometabolicos entre escolares nascido a término y preterminos
}

Received: 24/02/2021 | Reviewed: 03/03/2021 | Accept: 11/03/2021 | Published: 18/03/2021

\author{
Geruza Mara Hendges \\ ORCID: https://orcid.org/0000-0003-0388-4510 \\ Federal University of Paraná, Brazil \\ E-mail: geruza_hendges@hotmail.com \\ Elza Daniel Melo \\ ORCID: https://orcid.org/0000-0002-3577-0721 \\ Federal University of Rio Grande do Sul, Brazil \\ E-mail: elzadmello@gmail.com \\ Maria Lucia Bofleur \\ ORCID: https://orcid.org/0000-0001-5526-7421 \\ Western Paraná State University, Brazil \\ E-mail: mlbonfleur@ hotmail.com \\ Claudia Silveira Viera \\ ORCID: https://orcid.org/0000-0002-0900-4660 \\ Western Paraná State University, Brazil \\ E-mail: clausviera@gmail.com
}

\begin{abstract}
Objective: To assess the occurrence of cardiometabolic risk (RCmet) in children aged 5 to 9 years old born premature compared to those born at term. Methodology: Cross-sectional study in which children enrolled in urban municipal schools were evaluated. They were divided into two groups: low income and middle income, considering that the economic status is one of the social determinants of health. The total sample was of 132 children, classified according to their gestational age at birth in a group of schoolchildren born at term (GST) and a group of schoolchildren born prematurely (GSP), and assessed for weight, height, waist circumference (WC), blood pressure (BP), capillary blood glucose (CBG), total cholesterol (TC) and triglycerides (TG). RCmet was also analyzed in both groups according to the $\mathrm{WC}$ in the $>90$ th percentile and the $>50$ th percentile, associated with at least two of the following criteria: $\mathrm{TC} \geq 70$ $\mathrm{mg} / \mathrm{dL} ; \mathrm{TG} \geq 85 \mathrm{mg} / \mathrm{dL} ; \mathrm{CBG} \geq 126 \mathrm{mg} / \mathrm{dL}$; Systolic/diastolic $\mathrm{BP} \geq \mathrm{P} 90 \mathrm{mmHg}$, and the $\mathrm{WC}$ and height ratio (WCHR). Results: Among the GST with WC >P90, 10\% presented RCmet, while, for the WC >P50, 23.44\% presented this risk. In GSP, there were no participants with WC above P90; in those with WC >P50, 22.22\% had RCmet. Comparing the groups, there was no statistically significant difference. It was found that in $90.15 \%$ of the evaluations, there was an equivalent classification between the HR methods and the WC percentile. Conclusions: The occurrence of RCmet was evidenced in both groups, however, there was no influence of the age at birth on this risk.
\end{abstract}

Keywords: Pediatric obesity; Metabolic syndrome; Infant premature.

\begin{abstract}
Resumo
Objetivo: Avaliar a ocorrência de risco cardiometabólico (RCmet) em crianças de 5 a 9 anos de idade nascidas prematuras em comparação às nascidas a termo. Metodologia: Estudo transversal em que foram avaliadas crianças matriculadas em escolas municipais urbanas, as quais foram divididas em dois grupos: baixa renda e média renda, tendo-se em vista que a renda familiar possa ter efeito sobre a saúde da criança. A amostra total foi de 132 crianças, classificadas quanto à idade gestacional de nascimento em grupo de escolares nascidos a termo (GENT) e grupo de escolares nascidos prematuros (GENP) e avaliadas quanto ao peso, estatura, circunferência abdominal (CA), pressão arterial (PA), glicemia capilar (GC), colesterol total (CT) e triglicerídeos (TG). Analisou-se também o (RCmet) em ambos os grupos de acordo com a CA no percentil $>90$ e CA percentil $>50$, associado a pelo menos dois dos seguintes critérios: CT $\geq 170 \mathrm{mg} / \mathrm{dL} ; \mathrm{TG} \geq 85 \mathrm{mg} / \mathrm{dL} ; \mathrm{GC} \geq 126 \mathrm{mg} / \mathrm{dL}$; PA sistólica/diastólica $\geq \mathrm{P} 90 \mathrm{mmHg}$, e a relação CA e estatura (RCE). Resultados: Entre os GENT com percentil de CA >P90, 10\% apresentou RCmet, enquanto para o percentil de CA >P50, 23,44\% apresentou esse risco. No GENP, não houve participantes com CA acima do P90; naquelas com CA >P50, 22,22\% apresentou RCmet. Comparando-se os grupos, não foi observada diferença estatística significativa entre eles. Conclusões: Evidenciou-se ocorrência de RCmet em ambos os grupos, contudo, não houve diferença estatística significativa entre o GENT e GENP.
\end{abstract}

Palavras-chave: Obesidade pediátrica; Síndrome metabólica; Recém-nascido prematuro. 


\begin{abstract}
Resumen
Objetivo: Evaluar la aparición de riesgo cardiometabólico (RCmet) en niños de 5 a 9 años de edad nacidos prematuros en comparación con los nacidos a término. Metodología: Estudio transversal que evalúa a niños matriculados en escuelas municipales áreas urbanas, que se dividieron en dos grupos: ingresos bajos y medios, teniendo en cuenta que los ingresos familiares pueden afectar la salud del niño. La muestra total fue de 132 niños, clasificados según su edad gestacional al nacer en un grupo deescolares de término (GENT) y grupo de escolares prematuros (GENP) y evaluado por peso, altura, circunferencia de la cintura (CC), presión arterial (PA), glucosa en sangre capilar (GC), colesterol total (CT) y triglicéridos (TG). También se analizó el riesgo cardiometabolico (RCmet) en ambos los grupos de acuerdo con la CA en el percentil $>90$ y percentil CA $>50$, asociado con al menos dos de los siguientes criterios: CT $\geq 170 \mathrm{mg} / \mathrm{dL} ; \mathrm{TG} \geq 85 \mathrm{mg} / \mathrm{dl} ; \mathrm{GC} \geq 126 \mathrm{mg} / \mathrm{dl} ; \mathrm{PA}$ sistólica/diastólica $\geq \mathrm{P} 90 \mathrm{mmHg}$ y la relación CA y talla (RCE).

Resultados: Entre los GENT con percentil de CA >P90, 10\% tenía RCmet, mientras que para el percentil CA >P50, el 23,44\% tenía este riesgo. En GENP, no hubo participantes con CA arriba de P90; en aquellos con CA >P50, 22,22\% presentó RCmet. Comparando los grupos, no se observó diferencia estadística significativo entre ellos. Conclusiones: La ocurrencia de RCmet se evidenció en ambosgrupos, sin embargo, no hubo diferencias estadísticamente significativas entre GENT y GENP.
\end{abstract}

Palabras clave: Obesidad pediátrica; Síndrome metabólico; Recien nacido prematuro.

\title{
1. Introduction
}

Worldwide, birth before the 37th week of pregnancy is the main cause of death among children under five years of age, (Who, 2012) being an important risk factor for changes in child development and growth. (Cardoso, \& Betiol, 2015) The increase of premature births in the world has become worrying. In 2014, $10.6 \%$ of live births worldwide were premature, which is equivalent to 14.84 million preterm newborns born alive. (Chawanpaiboon et al., 2019) In Brazil, the prematurity rate is estimated at $11.5 \%$, that is, about 345,000 children, out of a total of $3,000,000$ births. (SBP, 2017)

In the intrauterine phase, fetal development is influenced by adverse factors, which can culminate in the development of a hostile environment for the fetus. (Marciniak et al., 2017; Eberle \& Ament, 2012) The nutritional, hormonal and metabolic environment provided by the mother alters the organ structure, cellular responses and gene expression, which affect the metabolism and physiology of their offspring. These changes can induce adverse effects on the fetus that do not manifest until long after birth. (Bussler et al., 2017) In this context, premature infants (PT) are subject to numerous repercussions throughout their lives due to intrauterine changes and prematurity itself. (Schmitt et al., 2016) Among the late repercussions of prematurity, arterial hypertension and dyslipidemia can be mentioned as factors that are prone to the development of metabolic syndrome (MS). (Sipola-Leppanen et al., 2015; Chatmethakul \& Roghair, 2019)

Thus, young adults aged between 29 and 30 years who were born premature have increased risk factors for the development of MS, it is explained as a group of manifestations which includes obesity, insulin resistance, dyslipidemia and hypertension. Linked to these manifestations are type 2 diabetes mellitus (T2DM) and cardiovascular diseases. (SBP, 2017; Bussler et al., 2017; Kopec et al., 2017; Backer, Bergmann \& Ogra, 2008) For the investigation of MS, waist circumference (WC) is one of the measures used, and which is considered as an independent condition that predicts cardiovascular risk in adults and children. Children with WA >P90 are more prone to multiple risk factors than children below this percentile. (Burgos et al., 2013; Damiani et al., 2011) Therefore, increased WC is considered to be one of the main risk factors for coronary heart disease associated with an increased prevalence of arterial hypertension, dyslipidemia and T2DM. The use of the waist/height ratio (WHR) is the best predictor of adiposity in children and adolescents for cardiovascular risk, to the detriment of the body mass index used alone. Thus, the child is advised to keep the WC below half his height. (Santos et al., 2019)

Even with the increase in metabolic changes in children and the increase in childhood obesity, there is still no welldefined diagnostic criterion for MS for this group, (Bussler et al., 2017; Chen \& Berenson, 2007) especially for those under 10 years of age. (SBP, 2017) Evidence of MS markers is found in studies with adolescents (Wicklow et al., 2015; Nambiar et al., 2013; Shie et al., 2013) or with term-born schoolchildren. (Andaki et al., 2018, Shim et al., 2018, Ahrens et al., 2014) The 
definition of MS in children under 10 years of age was proposed by European researchers in a study that evaluated children in eight countries and showed clinical relevance in identifying children at risk of MS as early as possible, as they would likely benefit from lifestyle changes. (Ahrens et al., 2014)

In children under 10 years of age, cardiometabolic changes may be subtle, appearing slowly and progressively. Therefore, early screening, especially in overweight and obese children, is essential, even without a family history of cardiovascular disease or T2DM. (Damiani et al., 2011) Anthropometric indicators are associated with cardiometabolic risk factors (RCmet).

However, there is no consensus on which indicator is the most appropriate. (Quadros et al., 2019) In view of the greater number of premature births and the relationship pointed out in the literature between prematurity and metabolic changes throughout life, (Chatmethakul et al., 2019, Schimitt et al., 2016, Sipola-Leppane et al., 2015) this study aims to assess the occurrence of cardiometabolic risk in children aged 5 to 9 years old born premature, compared to those born at term. Early identification of high-risk children will facilitate the implementation of appropriate screening programs for MS and its components at an early stage of life.

\section{Methodology}

It is an epidemiological study, defined as the distribution and determinants research of diseases or health-related conditions, in a specified population (Bonita et al., 2010). In our study, this particular group was composed by students from public elementary schools, in western Paraná-Brazil. The epidemiological investigation developed was classified as an analytical-observational study, conducted through a cross-sectional design. In this kind of research, the exposure and the health condition of the participants are observed simultaneously. In general, this type of investigation begins with the determination of the disease prevalence or the health condition related to a specified group. Next, the relationship between individuals with and without the disease is established (Bonita et al., 2010). In our case, the connection was set up between schoolchildren born at term or premature with cardiometabolic risk, and then compared to those without this risk.

The study sampling was a convenience type, totaling 132 children aged 5 to 9 years old, born at term and premature. These were listed in the survey through stratification by family income at low (0.80-1.70 wages) and average (2.83-5.08 wages). (Abep, 2016)

The variables analyzed in the study were: height, weight, blood pressure, WC, WHR and biochemical tests (glucose, total cholesterol and triglycerides).

Therefore, in the collection protocol established for this investigation, the height was verified with the child in vertical position with both feet together and heel leaning against the column of the Sanny® stadiometer, model Standard, with scale in millimeters. Weight was measured with a Lider® digital scale, model P200, recorded in kilograms. The body mass index (BMI) was calculated using the weight and height and classified according to the cut-off point of the Z-score, recommended by the World Health Organization. [1] WC was checked with an inelastic tape positioned at the midpoint between the lower margin of the last rib and the upper edge of the iliac crest, with the child standing, and recorded in centimeters. Blood pressure (BP) was checked with Onrom ${ }^{\circledR}$ digital wrist sphygmomanometer on the right upper limb after 10 minutes of rest. Two measurements were taken with an interval of five minutes between them, with the average of these measurements and classification according to the sex and age table available at the Ministry of Health. (Brasil, 2012)

Biochemical tests were collected by capillary puncture, without fasting, since the children were at school. Blood Capillary Glucose (BCG) was measured by GTech ${ }^{\circledR}$ device. As there are no glycemic reference parameters for children below 10 years of age, it was decided to adopt in this study the guidelines of the Brazilian Diabetes Society, (SBD, 2019) which states $<100 \mathrm{mg} / \mathrm{dL}$ as the value expected for children above 10 years of age. Total cholesterol (TC) and triglycerides (TG) were 
measured using the Roche's Accutrend Plus ${ }^{\circledR}$ device. The TC was presented in the measurement range of $150-300 \mathrm{mg} / \mathrm{dL}$, with a coefficient of variation of 0.8 to $3.7 \%$. TG was presented in the measurement range of $70-600 \mathrm{mg} / \mathrm{dL}$ with a coefficient of variation of 3.1 to $3.4 \%$, according to the manufacturer's specifications. The values were compared to the desirable reference lipid profile for children presented by Scartezini et al. (2017): TC $=<170 \mathrm{mg} / \mathrm{dL} ; \mathrm{TG}<85 \mathrm{mg} / \mathrm{dL}$, both without fasting.

The RCmet analysis of the studied sample was performed using the WC classification. The reference table of WC parameters in children aged 5 to 9 years was the one described by Freedman, Serdula and Srinivasan (1999) which groups children with $\mathrm{WC}$ in $\geq \mathrm{P} 50$ and $<\mathrm{P} 90$; and $\mathrm{WC} \geq \mathrm{P} 90$. In this study, as PT infants with WC $\geq 90$ were not identified, it was decided to include participants with WC $\geq$ P50 in the analysis of both groups. Only those born at term were classified with both $\mathrm{WC} \geq \mathrm{P} 90$ and $\mathrm{WC} \geq \mathrm{P} 50$, in order to identify the $\mathrm{RCmet}$ among these children and enable the comparison between term and preterm infants.

To perform the RCmet analysis, in addition to the analysis of $\mathrm{WC} \geq \mathrm{P} 90$ and $\mathrm{WC} \geq \mathrm{P} 50$, clinical and laboratory data were used. For this purpose, the group of schoolchildren born at term (GST) and the group of schoolchildren born premature (GSP) were grouped in relation to the referred percentiles of WC, and both groups classified according to RCmet, identified in the association of the percentile of WC to lipid, glycemic or blood pressure changes.

First, the RCmet of those with $\mathrm{WC} \geq \mathrm{P} 90$ was characterized, and those who exhibited two or more of the preestablished clinical criteria were marked as "yes", indicating the presence of RCmet. Otherwise, they received "no", which indicated no risk. The same logic was applied for GST and GSP with WC $\geq \mathrm{P} 50$, in order to identify the RCmet of these groups.

To verify the RCmet in GST and GSP with percentile of $\mathrm{WC} \geq \mathrm{P} 90$ and $\mathrm{WC} \geq \mathrm{P} 50$, the Chi-square test for kproportions was performed, with 5\% statistical significance. The GST and GSP groups, with a WC $\geq \mathrm{P} 50$ percentile, were compared using the Chi-square test for independence, followed by the Monte Carlo follow-up test, when necessary.

In addition to the RCMet analysis, according to the WC percentile, we chose to analyze the relationship between WC and height ratio (WHR), considered to be a reliable measure by the Brazilian Society of Pediatrics to identify visceral fat, which considers values above 0.50 equivalent to an altered condition. Thus, in order to carry out the study on the primary indicator of RCMet, linked to the WHR, this measure was crossed with clinical and laboratory data from the GST and GSP groups.

Since there were no statistical differences between children born at term and preterm, all variables in study were compared between the conditions "altered" (WHR >0.5) and "normal" (WHR <0.5). The quantitative variables (weight, height percentile, WC, BMI, Mean Systolic BP (MSBP), Mean Diastolic BP (MDBP), BCG and time of the last meal in minutes were evaluated in relation to the distribution pattern using the Shapiro Wilk and the homogeneity of the variances, using the F test. Since these assumptions were not considered, the comparison between the aforementioned conditions was performed using the Mann-Whitney-U non-parametric test.

Qualitative variables (Z-score for BMI, BCG, TC, TG, NSBO, MDBP, RCMet) were also compared between conditions using the Chi-square test for independence, followed by the follow-up test for residuals adjusted when necessary. Finally, calculations were performed to assess the validity of the primary risk method WHR in relation to the standard method percentile of WC. For this purpose, the following were calculated: Correct classification, Incorrect classification, Sensitivity, Specificity, False positive rate, False negative rate, Prevalence, Positive predictive value (PPV) and Negative predictive value (NPV). All analyses were performed using the XLSTAT Version 2017 program, (Addinsoft, 2017) assuming a 0.05 significance level.

The study followed all ethical precepts postulated in resolution 496/2012 and was approved by the Ethics and Research Committee under opinion No. 2.625.378, respecting all ethical precepts of research with human beings. It is 
noteworthy that the parents or guardians of the child signed the free informed consent term, and the child signed the research assent form before data collection.

\section{Results and Discussion}

The study results were obtained by the RCmet analyses among schoolchildren, as the study design presented in the Figure 1 below.

Figure 1: Study design for RCmet analysis. Toledo-PR, Brazil, 2020.

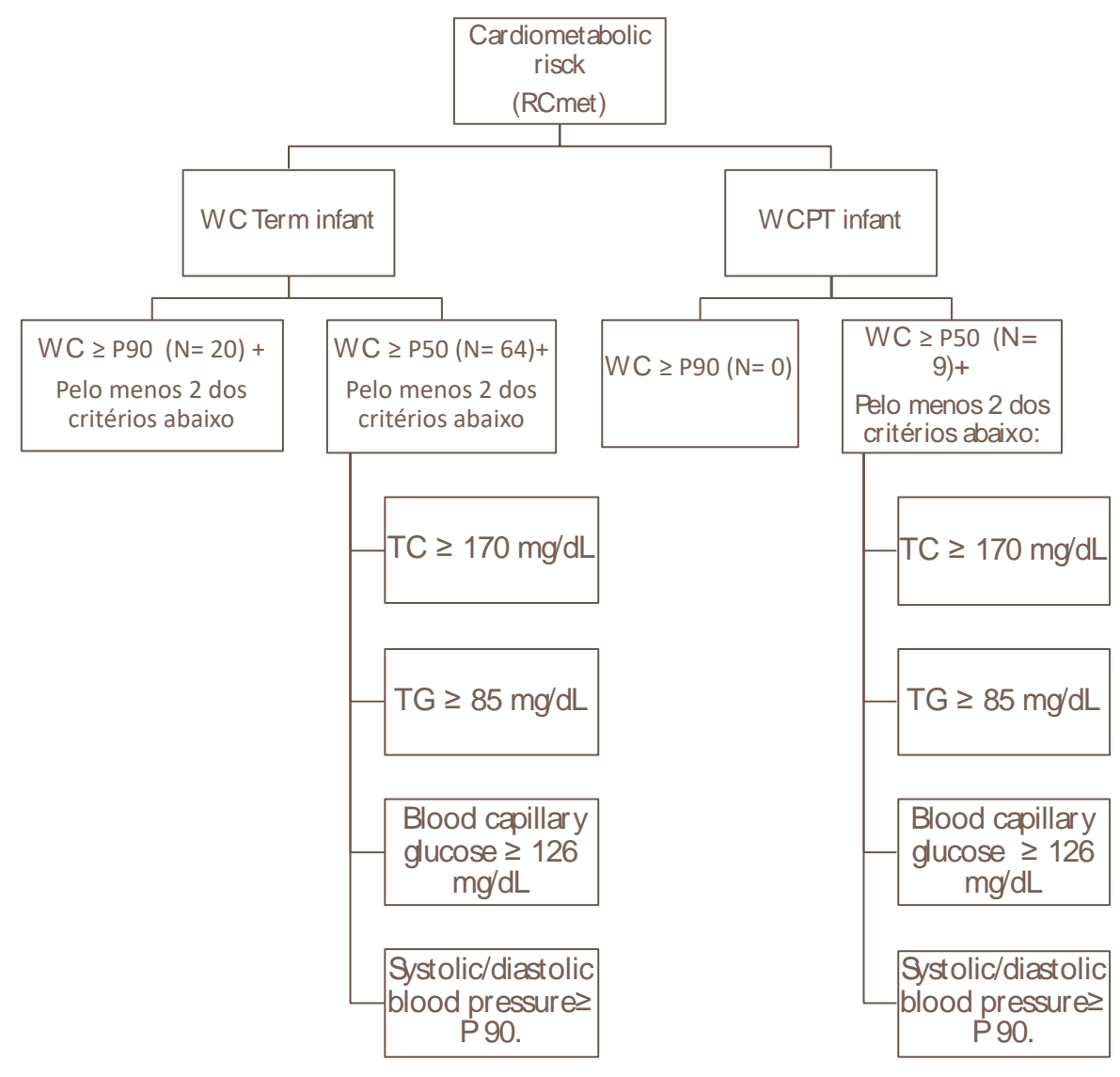

Source: Research data set.

The Figure 1 describes the analyses of RCmet based on the classification of the schoolchildren in two groups, one conformed by those born at term and other born prematurely. As well as the RCmet was linked to the percentile WC $\geq$ P50 and $<\mathrm{P} 90$ and $\geq \mathrm{P} 90$ of WC.

The RCmet among children born at term with $\mathrm{WC} \geq \mathrm{P} 90$ can be seen in Table 1 . 
Table 1: Presence and absence of clinical criteria that indicate cardiometabolic risk in full-term children with an WC percentile greater than 90. Toledo, Paraná, Brazil, 2020. (N=20).

\begin{tabular}{|c|c|c|c|}
\hline Variable & Category & n (\%) & p-value* \\
\hline RCmet & $\begin{array}{l}\text { No } \\
\text { Yes }\end{array}$ & $\begin{array}{l}18(90,00) \\
2(10,00)\end{array}$ & $<0,001$ \\
\hline MSBP & $\begin{array}{l}<\mathrm{P} 90 \\
\geq \mathrm{P} 90\end{array}$ & $\begin{array}{l}19(95,00) \\
1(5,00)\end{array}$ & $<0,001$ \\
\hline MDBP & $\begin{array}{l}<\mathrm{P} 90 \\
\geq \mathrm{P} 90\end{array}$ & $\begin{array}{l}19(95,00) \\
1(5,00)\end{array}$ & $<0,001$ \\
\hline $\mathrm{TG} \mathrm{mg} / \mathrm{dL}$ & $\begin{array}{l}<85 \\
\geq 85\end{array}$ & $\begin{array}{c}18(90,00) \\
2(10,00)\end{array}$ & $<0,001$ \\
\hline $\mathrm{TC} \mathrm{mg} / \mathrm{dL}$ & $\begin{array}{l}<170 \\
\geq 170\end{array}$ & $\begin{array}{l}20(100,00) \\
0(0,00)\end{array}$ & - \\
\hline BCG mg/dL & $\begin{array}{l}<126 \\
\geq 126\end{array}$ & $\begin{array}{l}9(45,00) \\
11(55,00)\end{array}$ & 0,527 \\
\hline
\end{tabular}

*p-value of Chi-Square for k-proportion $(\alpha=0.05)$.

RCmet $=$ Cardiometabolic risk; MSBP $=$ Mean of Systolic Blood Pressure; MDBP $=$ Mean of Diastolic Blood Pressure; $\mathrm{TG}=$ triglycerides; $\mathrm{TC}=$ Total Cholesterol; $\mathrm{BCG}=$ Blood Capillary Glucose. Source: Research data set.

The frequencies of individuals with the presence and absence of each clinical criterion analyzed as indicative of RCmet presented in the Table 1 showed most individuals, with a percentage of $\mathrm{WC} \geq 90$, did not present $\mathrm{RCmet}(90 \%)$. As well as changes to pressure (MSBP and MDBP $<$ P90) or lipid (TG $<85 \mathrm{mg} / \mathrm{dL}, \mathrm{CT}<170 \mathrm{mg} / \mathrm{dL}$ ) were not identified. Although no statistical difference was identified between the presence and absence of individuals with BCG $(\mathrm{p}=0.527)$, in percentage terms, it was possible to verify that $55 \%$ had a higher incidence of glycemic alterations (Table 1).

The RCmet for children born at term and preterm with $\mathrm{WC} \geq \mathrm{P} 50$ and $<$ P90 is shown in Table 2, presenting the frequencies of individuals with presence and absence of each clinical criterion (MSBP, MDBP, TG, TC and BCG). 
Table 2: Presence and absence of RCmet clinical criteria among children who born at term with WC $>50 *(\mathrm{~N}=64)$. Toledo, Parana, Brazil, 2020.

\begin{tabular}{c|l|c|l}
\hline Variable & \multicolumn{1}{|c|}{ Category } & n (\%) & \multicolumn{1}{c}{ p-value* } \\
\hline RCmet & No & $49(76,56)$ & $<0,001$ \\
& Yes & $15(23,44)$ & \\
\hline MSBP & $<\mathrm{P} 90$ & $59(92,19)$ & $<0,001$ \\
& $\geq \mathrm{P} 90$ & $5(7,81)$ & \\
\hline MDBP & $<\mathrm{P} 90$ & $57(89,06)$ & $<0,001$ \\
& $\geq \mathrm{P} 90$ & $7(10,94)$ & \\
\hline \multirow{2}{*}{ TG mg/dL } & $<85$ & $11(17,19)$ & $<0,001$ \\
\hline \multirow{2}{*}{ TC mg/dL } & $\geq 85$ & $57(89,06)$ & $<0,001$ \\
& $<170$ & $7(10,94)$ & \\
\hline \multirow{2}{*}{ BCG mg/dL } & $\geq 170$ & $27(42,19)$ & 0,077 \\
& $<126$ & $37(57,81)$ & \\
\hline
\end{tabular}

* Aggregation of classes whose percentiles were between 50 and 90.

$* *$ p-value of Chi-Square for k-proportion $(\alpha=0.05)$.

RCmet $=$ Cardiometabolic risk $;$ MSBP $=$ Mean of Systolic Blood Pressure $;$ MDBP $=$ Mean of Diastolic Blood Pressure; $\mathrm{TG}=$ triglycerides; $\mathrm{TC}=$ Total Cholesterol; $\mathrm{BCG}=$ Blood Capillary Glucose. Source: Research data set.

In the Table 2, it can be identified the majority of children in the GST group with $\mathrm{WC} \geq \mathrm{P} 50$ did not present RCmet (76.56\%; $\mathrm{p}<0.001)$. It was identified that the majority of children did not present pressure (MSBP and MDBP < P90) or lipid changes (TG <85 mg/dL, CT <170 mg/dL) ( $<<0.001)$. Regarding the glycemic profile, although no statistical difference was identified between the presence and absence of individuals with BCG ( $\mathrm{p}=0.077)$, the percentage was higher in individuals with glycemic alterations $(57.81 \%)$. However, there was a reduction in the percentage of cases without risk, in relation to those observed on table 1 , in those with $\mathrm{WC} \geq \mathrm{P} 90$ (90.00\%).

In Table 3 is showed the presence and absence of clinical criteria that indicate cardiometabolic risk in premature children with a WC percentile greater than 50 . 
Table 3: Presence and absence of clinical criteria that indicate cardiometabolic risk in premature children with a WC percentile greater than $50 *(\mathrm{~N}=9)$. Toledo, Paraná, Brazil, 2020.

\begin{tabular}{|c|c|c|c|}
\hline Variable & Category & n (\%) & p-value $* *$ \\
\hline RCmet & $\begin{array}{l}\text { No } \\
\text { Yes }\end{array}$ & $\begin{array}{l}7(77,78) \\
2(22,22)\end{array}$ & 0,018 \\
\hline MSBP & $\begin{array}{l}<\mathrm{P} 90 \\
\geq \mathrm{P} 90\end{array}$ & $\begin{array}{l}9(100,00) \\
0(0,00)\end{array}$ & - \\
\hline MDBP & $\begin{array}{l}<\mathrm{P} 90 \\
\geq \mathrm{P} 90\end{array}$ & $\begin{array}{l}7(77,78) \\
2(22,22)\end{array}$ & 0,018 \\
\hline $\mathrm{TG} \mathrm{mg} / \mathrm{dL}$ & $\begin{array}{l}<85 \\
\geq 85\end{array}$ & $\begin{array}{l}9(100,00) \\
0(0,00)\end{array}$ & - \\
\hline $\mathrm{TC} \mathrm{mg} / \mathrm{dL}$ & $\begin{array}{l}<170 \\
\geq 170\end{array}$ & $\begin{array}{l}9(100,00) \\
0(0,00)\end{array}$ & - \\
\hline BCG mg/dL & $\begin{array}{l}<126 \\
\geq 126\end{array}$ & $\begin{array}{l}3(33,33) \\
6(66,67)\end{array}$ & 0,157 \\
\hline
\end{tabular}

* Aggregation of classes whose percentiles were between 50 and 90.

$* *$ p-value of Chi-Square for k-proportion $(\alpha=0.05)$.

RCmet $=$ Cardiometabolic risk; MSBP = Mean of Systolic Blood Pressure; MDBP $=$ Mean of Diastolic Blood Pressure; TG = triglycerides; TC = Total Cholesterol; BCG = Blood Capillary Glucose. Source: Research data set.

In the analysis of RCmet among children in the GSP, evidenced in Table 3, it can be observed that there were statistical differences $(\mathrm{p}=0.018)$ between individuals classified with RCmet $(22 \%)$ and without $\mathrm{RCmet}(77.78 \%)$. The results demonstrate most of premature children do not present pressure or lipid changes. Nevertheless, when analyzing the glycemic profile, in $66.67 \%$ of them this index was greater than or equal to $126 \mathrm{mg} / \mathrm{dL}$, although, without statistically significant difference ( $p>0.05 ;$ Tab. 3).

From the characterization of GST and GSP in relation to RCmet with WC $\geq$ P50, a comparison was made between these groups, with no statistically significant difference between them $(\mathrm{p}=0.9356)$.

The Table 4 presented the quantitative variables analyses of the normal and altered groups in relation of the WC and height. 
Research, Society and Development, v. 10, n. 3, e34210313277, 2021

(CC BY 4.0) | ISSN 2525-3409 | DOI: http://dx.doi.org/10.33448/rsd-v10i3.13277

Table 4: Medians and interquartile ranges of quantitative variables related to the Normal and Altered groups, according to the ratio between waist circumference and height. Toledo, Parana, Brazil, 2020.

\begin{tabular}{|c|c|c|c|}
\hline Variables & $\begin{array}{c}\text { Normal } \\
\left(\mathrm{WHR}^{*} \leq \mathbf{0 . 5}\right)\end{array}$ & $\begin{array}{c}\text { Altered } \\
(\mathrm{WHR}>0.5)\end{array}$ & p-value** \\
\hline Weight & $25,8[23,0-30,4]$ & $43,5[36,8-47,0]$ & $<0,0001$ \\
\hline Height & $127,0[120,0-131,8]$ & $134,0[127,0-138,0]$ & 0,007315 \\
\hline Height percentile & $50,0[50,0-85,0]$ & $85,0[50,0-97,0]$ & 0,026641 \\
\hline WC & $55,0[52,0-59,0]$ & $76,0[70,0-84,5]$ & $<0,0001$ \\
\hline BMI & $16,4[15,5-18,0]$ & $23,5[21,7-27,0]$ & $<0,0001$ \\
\hline MSBP & $97,5[90,0-102,5]$ & $101,5[96,0-105,0]$ & 0,105066 \\
\hline MDBP & $61,5[57,0-68,0]$ & $62,0[58,0-68,0]$ & 0,772703 \\
\hline BCG & $105,0[98,0-114,0]$ & $107,0[98,0-114,0]$ & 0,614938 \\
\hline Time last meal (minutes) & $120,0[60,0-180,0]$ & $120,0[90,0-180,0]$ & 0,522049 \\
\hline
\end{tabular}

*WHR = relation between waist circumference and height; **p-value of Mann-Whitney-U test. WC $=$ waist circumference; BMI= body mass index; MSBP = Mean of Systolic Blood Pressure; MDBP = Mean of Diastolic Blood Pressure; BCG = Blood Capillary Glucose. Source: Research data set.

When comparing the quantitative variables between the conditions obtained by the WHR, the values of weight, height, height percentile, WC and BMI were significantly higher in the "altered" group, in relation to the GST and GSP considered "normal" ( $p>0.05$ ). The values of the variables MSBP, MDBP, BCG and time of the last meal in minutes were considered statistically equivalent between the groups under analysis (Table 4).

The qualitative variables' categories related to the Normal and Altered groups, according to the ratio between WC and height, can be observed in the Table 5 . 
Table 5: Absolute and relative frequencies in percentages (\%) of the qualitative variables' categories related to the Normal and Altered groups, according to the ratio between waist circumference and height. Toledo, Parana, Brazil, 2020.

\begin{tabular}{|c|c|c|c|c|}
\hline Variables & Categories & $\begin{array}{l}\text { Normal } \\
(\mathrm{WHR} \leq 0.5)\end{array}$ & $\begin{array}{l}\text { Altered } \\
(\text { WHR }>0.5)\end{array}$ & p-value* \\
\hline \multirow[t]{5}{*}{ Z-score BMI } & Thinness & $2[1,7 \%]$ & $0[0,0 \%]$ & $<0,0001$ \\
\hline & Eutrophy & $79[68,7 \%]$ & $0[0,0 \%]$ & \\
\hline & Overweight & $29[25,2 \%]$ & $2[11,8 \%]$ & \\
\hline & Obesity & $5[4,3 \%]$ & $8[47,1 \%]$ & \\
\hline & Severe Obesity & $0[0,0 \%]$ & $7[41,2 \%]$ & \\
\hline \multirow[t]{2}{*}{ Acanthosis (n[\%]) } & No & $112[100,0 \%]$ & $16[94,1 \%]$ & 0,0100 \\
\hline & Yes & $0[0,0 \%]$ & $1[5,9 \%]$ & \\
\hline \multirow[t]{2}{*}{$\mathrm{BCG}(\mathrm{n}[\%])$} & Normal & $42[36,5 \%]$ & $6[35,3 \%]$ & 0,916518 \\
\hline & Altered & $73[63,5 \%]$ & $11[64,7 \%]$ & \\
\hline \multirow[t]{2}{*}{ TC (n [\%]) } & Normal & $106[92,2 \%]$ & $16[94,1 \%]$ & 0,757044 \\
\hline & Altered & $9[7,8 \%]$ & $1[5,9 \%]$ & \\
\hline \multirow[t]{2}{*}{ TG (n [\%]) } & Normal & $103[89,6 \%]$ & $13[76,5 \%]$ & 0,135264 \\
\hline & Altered & $12[10,4 \%]$ & $4[23,5 \%]$ & \\
\hline \multirow[t]{3}{*}{$\operatorname{MSBP}(\mathrm{n}[\%])$} & $<\mathrm{P} 90$ & $109[94,8 \%]$ & $16[94,1 \%]$ & 0,433289 \\
\hline & $\mathrm{P} 90 \leq \mathrm{x} \leq \mathrm{P} 95$ & $2[1,7 \%]$ & $1[5,9 \%]$ & \\
\hline & $>\mathrm{P} 95$ & $4[3,5 \%]$ & $0[0,0 \%]$ & \\
\hline \multirow[t]{3}{*}{ MDBP (n[\%]) } & $<\mathrm{P} 90$ & $106[92,2 \%]$ & $14[82,4 \%]$ & 0,021434 \\
\hline & $\mathrm{P} 90 \leq \mathrm{x} \leq \mathrm{P} 95$ & $1[0,9 \%]$ & $2[11,8 \%]$ & \\
\hline & > P95 & $8[7,0 \%]$ & $1[5,9 \%]$ & \\
\hline \multirow[t]{2}{*}{ RCmet } & No & $115[100 \%]$ & 15 & 0,0002 \\
\hline & Yes & $0[0 \%]$ & 2 & \\
\hline
\end{tabular}

*p-value for Chi-Square test for Independence.

$\mathrm{WHR}=$ relation between waist circumference and height; $\mathrm{BMI}=$ Body Mass Index; $\mathrm{BCG}=\mathrm{Blood}$ Capillary $\mathrm{Glucose}$; $\mathrm{TC}=\mathrm{Total}$ cholesterol; $\mathrm{TG}=$ triglycerides;

MSBP = Mean of Systolic Blood Pressure; MDBP = Mean of Diastolic Blood Pressure; RCmet $=$ Cardiometabolic risk. Source: Research data set. 
As for the comparison of qualitative variables frequencies between groups, it was noted that only the variables: classification BMI Z-score, MDBP and RCMet showed statistically significant differences between children classified as "normal" and "altered" ( $\mathrm{p}<0.05$; Table 5). Considering the BMI Z-score, the frequencies of obesity and severe obesity were statistically higher among children classified with altered WHR. In addition, there was a higher frequency of MDBP between P90 and P95 in this same group. The frequency of children with RCmet was significantly higher among the group classified as "altered".

Finally, the sensitivity and specificity between the WHR method and the evaluation by the percentile of WC were calculated. It was evidenced in the Table 6 bellow.

Table 6: Metric of the validity of the primary risk method ratio waist circumference / height in relation to the percentile of waist circumference. Toledo-Parana, Brazil, 2020.

\begin{tabular}{llll}
\hline Analysis & Value & inferior limit (95\%) & superior limit (95\%) \\
\hline Right classification & 0,9015 & 0,8507 & 0,9523 \\
Inadequate classification & 0,0985 & 0,0477 & 0,1493 \\
Sensitivity & 0,6000 & 0,3861 & 0,7806 \\
Specificity & 0,9554 & 0,8963 & 0,9830 \\
False positive rate & 0,0446 & 0,0071 & 0,0822 \\
False negative rate & 0,4000 & 0,2040 & 0,5960 \\
Prevalence & 0,1515 & 0,0903 & 0,2127 \\
Positive predictive value & 0,7059 & 0,4893 & 0,9225 \\
Negative predictive value & 0,9304 & 0,8839 & 0,9769 \\
\hline
\end{tabular}

Source: Research data set.

It can be observed in the table $6,90.15 \%$ of the evaluations presented an equivalent classification between the WHR methods and the WC percentile. The sensitivity was $60 \%$ and specificity was $95.54 \%$. Thus, it can be said that the rate of false positives was $4.46 \%$, and false negatives, $40 \%$. The prevalence of children with primary prediction of RCMet evaluated by the WC percentile was $15.15 \%$, that is, 20 of 132 children evaluated. The positive predictive value was $70.59 \%$, which indicates that from 20 children originally classified with primary risk, using the WC percentile, only 14 would have the correct classification. The negative predictive value was 93.04\%, which indicates that from 112 children originally classified as healthy, using the WC percentile method, 104 would have the correct classification of being "healthy" (Table 6).

This investigation identified the potential RCmet among children born at term and preterm, for early recognition of RCmet in childhood. Thus, it was detected among children at term with WC $\geq \mathrm{P} 90$ and with $\mathrm{WC} \geq \mathrm{P} 50$ and $<\mathrm{P} 90,10 \%$ and 23.44\%, respectively, presented RCmet. In PT infants with $\mathrm{WC} \geq \mathrm{P} 50,22.22 \%$ had RCmet. When comparing the RCmet between the two groups, no statistically significant difference was observed.

It is important to note the presence of RCmet indicators in both GST and GSP children, when the risk expected in this assessment would be zero in view of the young age of the children. It was observed in GST, the predictive factors for RCmet were MSBP, MDBP, TG and BCG, while in the GSP was MDBP and BCG. Moreover, between GST with WC $\geq$ P90 and WC $\geq$ P50 and $<$ P90, those with $\mathrm{WC} \geq$ P50 had a higher frequency of children with parameters changed for age, plus TC and that was not changed between GST with WC $\geq \mathrm{P} 90$.

The scientific evidence comparing RCmet between preterm and full-term children is limited in our country. A study carried out in the USA, which analyzed a cohort of premature and full-term children, found out that full-term children with 
high birth weight and those considered to be large for gestational age born prematurely had an increased chance of obesity at school age when compared to children with normal birth weight. (Kapral et al., 2018) Among Brazilian schoolchildren aged 6 to 17 years, categorized into groups according to the RCmet components, it was observed that the greatest changes were the increased BMI, WC and subscapular fold. This assessment considered the variables weight, height, WC and thickness of the subscapular and tricipital skinfolds, BMI, WC, TC $\geq 170 \mathrm{mg} / \mathrm{dL}$, high density lipoprotein (HDL-c) $<45 \mathrm{mg} / \mathrm{dL}$, low density lipoprotein (LDL-c) $\geq 130 \mathrm{mg} / \mathrm{dL}, \mathrm{TG} \geq 130 \mathrm{mg} / \mathrm{dL}, \mathrm{BCG} \geq 100 \mathrm{mg} / \mathrm{dL}$ and blood pressure $\geq 95$ th percentile. (Quadros et al., 2019) However, this study does not identify the gestational age of schoolchildren, making it impossible to identify whether there was a difference between being born premature and at term in the presence of RCmet.

Premature children usually develop adiposity in early school age, probably due to the reduced number of neurons in the satiety center, resulting in increased food intake, culminating in proliferation and increased fat storage. (Perenc et al., 2019) In our study, although the GSP did not have WC $\geq$ P90, it was observed that in this group, children with WC between P50 and 90 had RCmet. A recent systematic review concluded that, due to age corrected by term, preterm infants have a 3\% higher percentage of fat mass compared to those born at term, which is largely explained by a deficit in lean body mass. (Louise et al., 2012)

Furthermore, in addition to the greater chance of abdominal adiposity, children under 37 weeks of gestational age are also subject to pressure changes, as evidenced in a population-based study using antihypertensive prescriptions. This study found that, in more than 600,000 individuals evaluated, premature newborns were more likely to use this type of medication. Although the increase in BP in young adults born prematurely is small (between 3-4 mm Hg), a decrease in DBP by only 2 $\mathrm{mmHg}$ can reduce the risk of myocardial infarction. (Dagle et al., 2014) In our study of premature children with a WC percentile $\geq \mathrm{P} 50$ and $<\mathrm{P} 90,22.22 \%$ showed changes in MDBP. Therefore, it is observed that among children at term, the elevation of blood pressure starts early. The same occurs among PT infant, with up to 70\% of them show high SBP in childhood, (Bayman et al., 2014) becoming a significant concern in adulthood, especially when associated with obesity. (Chatmethakul \& Roghair, 2019) In this sense, BP monitoring of premature infants should start before the age of three. (Dagle et al., 2011) Investigations show the complexity of interactions between obesity and hyperinsulinemia, which play an important role in arterial hypertension. (Carmo et al., 2016, Zhang et al., 2016)

The highest incidence of RCmet in adults, which includes arterial hypertension, insulin resistance and atherogenic lipid profile, was observed in a cohort of premature individuals (born before 34 weeks of gestational age) and late preterm (born between 34- 36 weeks gestational age), however, it is more present among those born with very low birth weight $(<1,500$ g) or those born very premature ( $<32$ weeks). (Parkinson et al., 2013, Pyhäiä et al., 2009) In addition, the predisposition to arterial hypertension and dyslipidemia, in those prematurely born children, become pre-available factors for the development of MS. In view of the above, there is evidence that young adults aged between 29 and 30 years, who were born premature, have increased risk factors for the development of MS. (Sipola-Lappane et al., 2015)

In our study, a considerable percentage (66.6\%) of the GSP showed an increase in BCG. This fact was also observed in a cohort study that evaluated the RCmet by weight, height, BMI, BP, TC, TG, HDL-c, LDL-c, blood glucose, insulin and Homa index. The authors concluded that adults born with extreme prematurity have a four-fold increase in the risk of developing glycemic alterations in the fourth decade of life, as well as an increase in body adiposity and reduced lean mass for height, differences that contribute to their altered metabolic state. (Morrison et al., 2016)

Therefore, the results of studies in children require the interpretation of each value obtained according to the specific cutoff points for age and sex, and there is no specific treatment for RCmet-related changes. There is a need for preventive measures with a screening that should include: BMI, WC, BP, lipid profile, serum glucose and an oral glucose tolerance test, if indicated. The guidelines converge on the importance of changes in lifestyle, characterized by a nutritional program suitable 
for age and the practice of regular physical activity, keeping in mind that such interventions, even in the absence of weight loss, can have positive effects on the components of MS. (Bussler et al., 2017)

Although a study suggests that the waist-to-height ratio (WHR) is a better predictor for screening overweight children, as they found in the ROC curve analysis that the WHR index showed a greater area under the curve, (Vieira et al., 2018) in our study it was observed that the validation metrics for the WC measurement using the waist-height ratio method and the WC percentile showed greater sensitivity for the WC percentile.

\section{Conclusion}

Despite there is no statistical difference between the preterm and full-term children's groups, $10 \%$ of the full-term group, with a WC percentile greater than P90, presented RCmet, while for the WC percentile greater than P50, 23.44\% presented this risk. In the group of preterm infants, those with WC greater than P50, 22.22\% had RCmet. From these data, the importance of evaluating RCmet is demonstrated in the first years of the child's life, especially when they are born prematurely, which helps to implement early preventive measures and reduction of chronic diseases in adulthood.

As a limitation of this study, we pointed out the small sample and the study design (cross-sectional), that analyze the sample in one time as a picture. On this sense, for future studies it is necessary to improve the sample size to analyze the same population and establish the relation between schoolchildren with and without RCmet. In addition, we suggest a longitudinal study, in which ones the research's collect data more then one time.

\section{Acknowledgments}

We would like to thank the study's executive team and the State University of Western Paraná - Campus Cascavel for enabling the development of the research.

\section{Funding}

Thank you, CNPQ, for the partial encouragement of research (Edital Universal 014/2014, approved by process 452639 / 2010-2).

\section{References}

Abep - Associação Brasileira de Empresas de Pesquisas. (2016). Critério Brasil 2015 e atualização da distribuição de classes para 2016. ABEP - Associação Brasileira de Empresas de Pesquisa. www.abep.org.Addinsoft. XLSTAT. (2017). Data analysis and statistics with Microsoft Excel, Paris, France.

Ahrens, W., Moreno, L. A., Mårild, S., Molnár, D., Siani, A., De Henauw, S., Böhmann, J., Günther, K., Hadjigeorgiou, C., Iacoviello, L., Lissner, L., Veidebaum, T., Pohlabeln, H., \& Pigeot, I. (2014). Metabolic syndrome in young children: definitions and results of the IDEFICS study. International Journal of Obesity, 38(S2), S4-S14. https://doi.org/10.1038/ijo.2014.130.https://doi.org/10.1038/ijo.2014.130.

Andaki, A. C. R., Mendes, E. L., Santos, A., Brito, C., Tinôco, A. L. A., \& Mota, J. (2018). Waist circumference percentile curves as a screening tool to predict cardiovascular risk factors and metabolic syndrome risk in Brazilian children. Cad Saude Publica, 34(9). https://doi.org/10.1590/0102-311x00105317.

Backer, D. J. P., Bergamann, R. L., \& Ogra, P. L. (2008). The window of opportunity: pre-pregnancy to 24 months of age. S Karger, 61:103-121.

Bayman, E., Drake, A. J., \& Piyasena, C. (2014). Prematurity and programming of cardiovascular disease risk: a future challenge for public health? Arch Dis Child Fetal Neonatal Ed, 99(6):514-4. https://doi.org/10.1136/archdischild-2014-306742.

Bonita, R., Beaglehole, R., \& Kjellstrom, T. (2010). Epidemiologia Básica. Santos.

Brasil. (2012). Ministério da Saúde. Secretaria de Atenção à Saúde. Departamento de Atenção Básica. Cadernos de Atenção Básica 33. Brasília: Ministério da Saúde. Available from: https://bvsms.saude.gov.br/bvs/publicacoes/saude_crianca_crescimento_desenvolvimento.pdf

Burgos, M. S., Burgos, L. T., Camargo, M. D., Ranke, S. I. R, Prá, D., Silva, A. et al. (2013). Associação entre medidas antropométricas e fatores de risco cardiovascular em crianças e adolescentes. Arq Bras Cardiol, 101(4):288-296. https://doi.org/10.5935/abc.20130169. 
Bussler, S., Penke, M., Flemming, G., Elhassan, Y. S., Kratzsch J., Sergeyev, E. et al. (2017). Novel insights in the metabolic syndrome in childhood and adolescence. Horm Res Paediatr, 88:181-193.

Cardoso, V. C, \& Bettiol, H. (2015). Consequências metabólicas tardias da prematuridade. In: Procianoy, R. S., Leone, C. R. (Org.). PRORN - Programa de Atualização em Neonatologia. Artmed Panamericana.

Carmo, J. M., Silva, A. A., Wang, Z., Freeman, N. J., Alsheik, A. J., Adi, A., \& Hall, J. E. (2016). Regulation of blood pressure, appetite, and glucose by leptin after inactivation of insulin receptor substrate 2 signaling in the entire brain or in proopiomelanocortin neurons. Hypertension, 67(2):378-386. https://doi.org/ 10.1161/HYPERTENSIONAHA.115.06153.

Chatmethakul, T., \& Roghair, R. D. (2019). Risk of hypertension following perinatal adversity: IUGR and prematurity. Journal the Endocrinology, 242:1. https://doi.org/10.1530/JOE-18-0687.

Chawanpaiboon, S., Vogel, J. P., Moller, A. B., Lumbiganon, P., Petzold, M., Hogan, D. et al. (2019). Global, regional, and national estimates of levels of preterm birth in 2014: a systematic review and modelling analysis. Lancet Glob Health, 7(1):e37-e46 https://doi.org/10.1016/S2214-109X(18)30451-0.

Chen, W., \& Berenson, G. S. (2007). Metabolic syndrome: definition and prevalence in children. J Pediatr, 83(1):64-70. https://doi.org/10.2223/JPED.1583.

Dagle, J. M., Fisher, T. J., Haynes, S. E., Berends, S. K., Brophy, P. D., Morriss, F. H. Jr, \& Murray, J. C. (2011). Cytochrome P450 (CYP2D6) Genotype is associated with elevated systolic blood pressure in preterm infants following NICU discharge. J Pediatr, 159(1):104-109. https://doi.org/10.1016/j.jpeds.2011.01.002.

Damiani, D., Kuba, V. M., Cominato, L., Dichtchekenian, V., \& Menezes Filho, H. C. (2011). Síndrome metabólica em crianças e adolescentes: dúvidas na terminologia, mas não nos riscos cardiometabólicos. Arq Bras Endocrinol Metabol, 55(8):576-582. https://doi.org/10.1590/S0004-27302011000800011.

Eberle, C., \& Ament, C. (2012). Diabetic and metabolic programming: mechanisms altering the intrauterine milieu. ISRN Pediatr. https://doi.org/10.5402/2012/975685.

Freedman, D. S., Serdula, M. K., \& Srinivasan, S. R. (1999). Relation of circumference and skinfold thicknesses to lipid and insulin concentrations in children and adolescents: the Bogalusa Heart Study. Am J Clin Nutr. 69(2):308-17. https://doi.org/10.1093/ajcn/69.2.308.

Kapral, N. B. S., Miller, S. E., Scharf, R. J., Gurka, M. J., \& DeBoer, M. D. (2018). Associations between birthweight and overweight and obesity in schoolage children. Pediatr Obes, 13:6. https://doi.org/10.1111/ijpo.12227.

Kopec, G., Shekhawat, P. S., \& Mhanna, M. J. (2017). Prevalence of diabetes and obesity in association with prematurity and growth restriction. Diabetes Metab Syndr Obes, 10:285-295. https://doi.org/10.2147/DMSO.S115890.

Louise, T., Saud, A., Bendar, N., Durighel, G., Frost, G., \& Bell, J. (2012). The effect of preterm birth on adiposity and metabolic pathways and the implications for later life. Clinical Lipidology, 7(3):275-288. https://doi.org/ 10.2217/clp.12.32.

Marciniak, A., Patro-Małysza, J., Kimber-Trojnar, Ż., Marciniak, B., Oleszczuk, J., \& Leszczyńska-Gorzelak, B. (2017). Fetal programming of the metabolic syndrome. Taiwan J Obstet Gynecol, 56(2)133-138. https://doi.org/10.1016/j.tjog.2017.01.001.

Morrison, K. M., Ramsingh, L., Gunn, E., Streiner, D., Van Lieshout, R., Boyle, M., Gerstein, H., Schmidt, L., \& Saigal, S. (2016). Cardiometabolic health in adults born premature with extremely low birth weight. Pediatrics, 138:4. https://doi.org/0.1542/peds.2016-0515.

Nambiar, S., Truby, H., Davies, P. S., \& Baxter, K. (2013). Use of the waist-height ratio to predict metabolic syndrome in obese children and adolescents. J Paediatr Child Health, 49(4). https://doi.org/10.1111/jpc.12147.

Parkinson, J. R., Hyde, M. J., Gale, C., Santhakumaran, S., \& Modi, N. (2013). Preterm birth and the metabolic syndrome in adult life: a systematic review and meta-analysis. Pediatrics, 131(4):e1240-e1263.

Perenc, L., Zajkiewicz, K., Drzał-Grabiec, J., Cyran-Grzebyk, B., \& Walicka-Cupryś, K. (2019). Assessment of body adiposity in preterm children at the beginning of school age. Scientific Reports, 9:6207. https://doi.org/10.1038/s41598-019-42715-8.

Pyhälä, R., Räikkönen, K., Feldt, K., Andersson, S., Hovi, P., Eriksson, J. G., Järvenpää, A. L., \& Kajantie, E. (2009). Blood pressure responses to psychosocial stress in young adults with very low birth weight: Helsinki Study of Very Low Birth Weight Adults. Pediatrics,123(2):731-734.

Quadros, T. M. B., Gordia, A. P., Andaki, A. C. R., Mendes, E. L., Mota, J., \& Silva, L. R. (2019). Utility of anthropometric indicators to screen for clustered cardiometabolic risk factors in children and adolescents. J Pediatr Endocrinol Metab, 32(1):49-55. https://doi.org/10.1515/jpem-2018-0217.

Santos, E. G. R., Pereira, P. Y., Sekiya, D. R. U., \& Goulart, R. M. M. (2019). Prevalência de risco cardiovascular a partir de parâmetros antropométricos em crianças e adolescentes. Revista Atenção à Saúde, 17(60):54-62. https://doi.org/10.13037/ras.vol17n60.5640.

SBD - Sociedade Brasileira de Diabetes. (2019). Diretrizes da Sociedade Brasileira de Diabetes: 2019-2020. Clannad. https://www.diabetes.org.br/profissionais/images/DIRETRIZES-COMPLETA-2019-2020.pdf.

SBP - Sociedade Brasileira de Pediatria. (2017). Novas orientações sobre o jejum para determinação laboratorial do perfil lipídico. Guia Prático de Atualização: Departamento Científico de Endocrinologia.

Scartezini, M., Ferreira, C. E. S., Izar, C., Bertoluci, M., Vencio, S., Campana, G. A. et al. (2017). Posicionamento sobre flexibilização do jejum para o perfil lipídico. Arq Bras Cardiol, 08(3):195-197.

Schmitt, J., Arnold, K., Druschke, D., Swart, E., Grählert, X., Maywald, U. et al. (2016). Early comprehensive care of preterm infants-effects on quality of life, childhood development, and healthcare utilization: study protocol for a cohort study linking administrative healthcare data with patient reported primary data. BMC pediatrics, 16, 104. https://doi.org/10.1186/s12887-016-0640-8 
Research, Society and Development, v. 10, n. 3, e34210313277, 2021

(CC BY 4.0) | ISSN 2525-3409 | DOI: http://dx.doi.org/10.33448/rsd-v10i3.13277

Shafiee, G., Kelishadi, R., Heshmat, R., Qorbani, M., Motlagh, M. E., Aminaee, T., et al. (2013). First report on the validity of a continuous Metabolic syndrome score as an indicator for Metabolic syndrome in a national sample of paediatric population - the CASPIAN-III study. Endokrynol Pol, 64(4):278-28. https://doi.org/10.5603/ep.2013.0006.

Shim, Y. S., Kang, M. I., Yang, S., \& Hwang, I. T. (2018). Irisin is a biomarker for metabolic syndrome in prepubertal children. Endocr J, 65(1):23-31. https://doi.org/10.1507/endocrj.EJ17-0260.

Sipola-Leppanen, M., Vääräsmäki, M., Tikanmäki, M., Matinolli, H. M., Miettola, S., Hovi, P., et al. (2015). Cardiometabolic risk factors in young adults who were born preterm. Am J Epidemiol, 181(11):861-873 https://doi.org/10.1093/aje/kwu443.

Vieira, S. A., Ribeiro, A. Q., Hermsdorff, H. H. M., Pereira, P. F., Priore, S. E., \& Franceschini, S. C. C. (2018). Índice relação cintura-estatura para predição do excesso de peso em crianças. Rev Paul Pediatr, 36(1):52-58. https://doi.org/ http://dx.doi.org/10.1590/1984-0462/,2018,36,1,00002.

Who - World Health Organization - WHO. (2012). Brazil: health profile. Geneva: WHO. http://www.who.int/gho/countries/bra.pdf.

Wicklow, B. A., Becker, A., Chateau, D., Palmer, K., Kozyrskij, A., \& Sellers, E. A. (2015). Comparison of anthropometric measurements in children to predict metabolic syndrome in adolescence: analysis of prospective cohort data. Int J Obes (Lond), 39:1070-1078. https://doi.org/10.1038/ijo.

Zhang, T., Zhang, H., Li, S., Li, Y., Liu, Y., Fernandez, C., Harville, E. et al. (2016). Impact of adiposity on incident hypertension is modified by insulin resistance in adults. Hypertension, 67:56-62. https://doi.org/ 10.1161/HYPERTENSIONAHA.115.06509. 